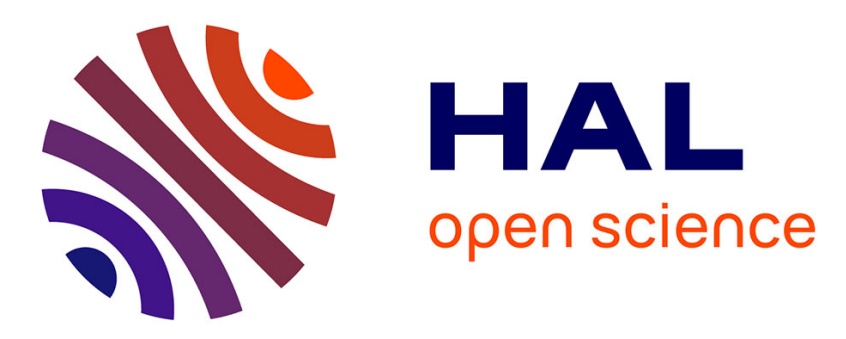

\title{
Effects of field characteristics on abundance of bumblebees (Bombus spp.) and seed yield in red clover fields
}

Kirstain H. Wermuth, Yoko L. Dupont

\section{- To cite this version:}

Kirstain H. Wermuth, Yoko L. Dupont. Effects of field characteristics on abundance of bumblebees (Bombus spp.) and seed yield in red clover fields. Apidologie, 2010, 41 (6), 10.1051/apido/2010038 . hal-00892099

\section{HAL Id: hal-00892099 \\ https://hal.science/hal-00892099}

Submitted on 1 Jan 2010

HAL is a multi-disciplinary open access archive for the deposit and dissemination of scientific research documents, whether they are published or not. The documents may come from teaching and research institutions in France or abroad, or from public or private research centers.
L'archive ouverte pluridisciplinaire HAL, est destinée au dépôt et à la diffusion de documents scientifiques de niveau recherche, publiés ou non, émanant des établissements d'enseignement et de recherche français ou étrangers, des laboratoires publics ou privés. 


\title{
Effects of field characteristics on abundance of bumblebees (Bombus spp.) and seed yield in red clover fields*
}

\author{
Kirstain H. WERMUTH, Yoko L. DUPONT \\ Aarhus University, Institute of Biology, Ny Munkegade building 1540, 8000 Aarhus C, Denmark
}

Received 4 November 2009 - Revised 11 January 2010 - Accepted 13 January 2010

\begin{abstract}
Red clover is a key floral ressource for bumblebees (Bombus spp.). We here investigate variation within and among red clover fields in species richness and abundance of Bombus spp. in addition to Apis mellifera. Bumblebee individuals were grouped into the following functional groups, based on castes and tongue length: (1) all queens, (2) all workers, (3) short-tongued workers and (4) long-tongued workers. In 14 study fields, no spatial or diurnal within-field differences were found in abundances of bee groups. However, seasonal differences were detected. On average $6.3 \pm 0.6$ Bombus spp. were observed in each field. In general, maximum observed bee abundances of a field were not associated with field size, weediness, or presence of commercial honeybee hives. However, long-tongued bumblebee abundance was significantly lower in fields with beehives. Seed yield was marginally higher in less weedy fields, but not significantly augmented by presence of bee hives.
\end{abstract}

Apis mellifera / crop pollination / short and long-tongued bumblebees / Trifolium pratense

\section{INTRODUCTION}

In 2006, Biesmeijer et al. presented convincing evidence of recent parallel declines of important pollinator groups, including bees, and specialist-pollinated plants in Europe. Bumblebees (Bombus Latreille spp.) are important pollinators of wild flowers and agricultural crops, and moreover are among some of the best known pollinating insect groups (Goulson, 2003; Benton, 2006; Goulson et al., 2008). Bumblebees are no exception to the general pattern of pollinator decline, particularly extinctions and decline of species are prevalent from 1950's onwards (Kosior et al., 2007; Colla and Packer, 2008; Grixti et al., 2009; Williams and Osborne, 2009). Many Bombus spp. appear on red lists in Europe (e.g. van der Smissen, 2001 (Germany); Madsen,

Corresponding author: Y.L. Dupont, yoko.dupont@biology.au.dk

* Manuscript editor: Stan Schneider
2009 (Denmark); www.artdata.slu.se/rodlista (Sweden); Benton, 2006 (UK)). Some species are more vulnerable than others, and several hypotheses have been proposed to explain this difference, including forage plant specialization (Rasmont and Mersch, 1988; Goulson, 2005; Carvell et al., 2006; Goulson et al., 2008) and climatic niche specialization but see (Williams, 2005; Williams et al., 2007, 2009).

The main driver of bumblebee decline is thought to be agricultural intensification, leading to fragmentation, loss and degradation of habitats and food sources due to changes in land use and agricultural practices, in addition to the use of pesticides and introduction of commercial bees (Goulson, 2005; Fitzpatrick et al., 2007; Kosior et al., 2007; Goulson et al., 2008; Murray et al., 2009; Williams and Osborne, 2009). Decline of important bumblebee forage plants have been documented (Corbet, 1995; Carvell et al., 2006). However, our knowledge of habitat 
requirements for nesting, mating and hibernation of Bombus spp. is very limited. Few studies have investigated the effects of habitats at the landscape scale on bumblebee abundance and diversity but see (Williams, 1988; Osborne et al., 2008a; Knight et al., 2009).

Among the declining bumblebees are several long-tongued Bombus spp. (Goulson, 2005). These species typically visit and pollinate long-tubed flowers, such as red clover (Fussell and Corbet, 1992). Red clover is a key floral resource of Bombus spp. (Carvell et al., 2005; Goulson, 2005; Carvell et al., 2006), and decline of red clover may have had a negative impact on bumblebee populations (Rasmont and Mersch, 1988; Carvell et al., 2006).

Once a common crop, particularly before the 1950's, red clover (Trifolium pratense L.) has become rare in Denmark and other North European countries (Rasmont and Mersch, 1988; Kleijn and Raemakers, 2008). Today, red clover is an important crop in organic farming due to its high resistance to insect pests and ability to grow on nutrient poor soils (C. Jørgensen, pers. commun.). Pollination is almost exclusively by bees (Stapel, 1933; Skovgaard, 1936; Delaplane and Mayer, 2000). It is generally agreed that bumblebees, specifically long-tongued species, are superior pollinators of red clover (Free, 1993), although honeybees (Apis mellifera L.) may under some circumstances contribute to pollination (Free, 1993; Delaplane and Mayer, 2000; Brødsgaard and Hansen, 2002). Seed yield of red clover has been decreasing for the past decades (C. Jørgensen, unpubl. data). It is, however, unknown if decreasing seed yields can be attributed to lack of pollination.

Bumblebee abundances and diversity differ within and among fields (Stapel, 1933; Skovgaard, 1936). We here investigate factors, which may affect abundances (visitation rates) of different functional groups of bumblebees, in addition to honeybees in red clover fields in Denmark. More specifically, we tested firstly the effect of time of the flowering season, diurnal observation time, and spatial location of the observation plot (edge, intermediate and center) within each field. We then test differences in bumblebee abundances among different fields in relation to geographical location, field sizes, presences/absence of commercial honeybee hives and weediness of the fields.

\section{MATERIALS AND METHODS}

\subsection{Fieldwork}

From the 20th of June to 6th of August 2008, we monitored bumblebee and honeybee abundances in 14 red clover fields in Eastern Jutland and Funen, Denmark (Fig. 1). All study fields were embedded in landscapes dominated by farmland, although surroundings encompassed fields, grassland, forest, hedgerows, and occasionally wetlands to varying extents. Fields were separated by at least $10 \mathrm{~km}$, although two fields were only two km apart (one of these was, however, excluded from the analysis). Each field was observed three times during the flowering season, preferably in the beginning (before peak flowering), the middle (at peak flowering) and in the end (after peak flowering) of the flowering season of red clover. Bumblebees were observed between 8 and $18 \mathrm{~h}$ under favorable weather conditions, i.e. no strong winds or rain. On each observation day, three plots of $18 \times 18 \mathrm{~m}$ (totalling $1000 \mathrm{~m}^{2}$ ) were placed on a line from the edge to the center of the field, with one at the edge, one intermediate and one at the centre. In every plot we walked slowly back and forth, observing each flower approximately once, and registering the number and identity of flower-visiting bumblebees. On each sampling occasion, we furthermore registered the starting time and time spent walking the plot. Each plot was walked 3-4 times on each sampling day. Sample specimens of bumblebees were collected for later identification by a taxonomic expert (Henning Bang Madsen, Copenhagen University). The closely related Bombus lucorum (L.), $B$. terrestris (L.), B. magnus Vogt and B. cryptarum (F.) are similar morphologically, and difficult to distinguish in the field, and therefore all individuals belonging to this species complex were registered as $B$. terrestris. Once during the field season, we assessed the weediness of the field (proportion of weeds). In addition, we obtained information about field size and presence/absence of commercial honeybee hives from the farmers. Presence of honeybee hives was defined as presence of at least one commercial hive in the field or in the field margin of the red clover field.

Seed yield data of each field were obtained from the seed companies DLF Trifolium Denmark and 


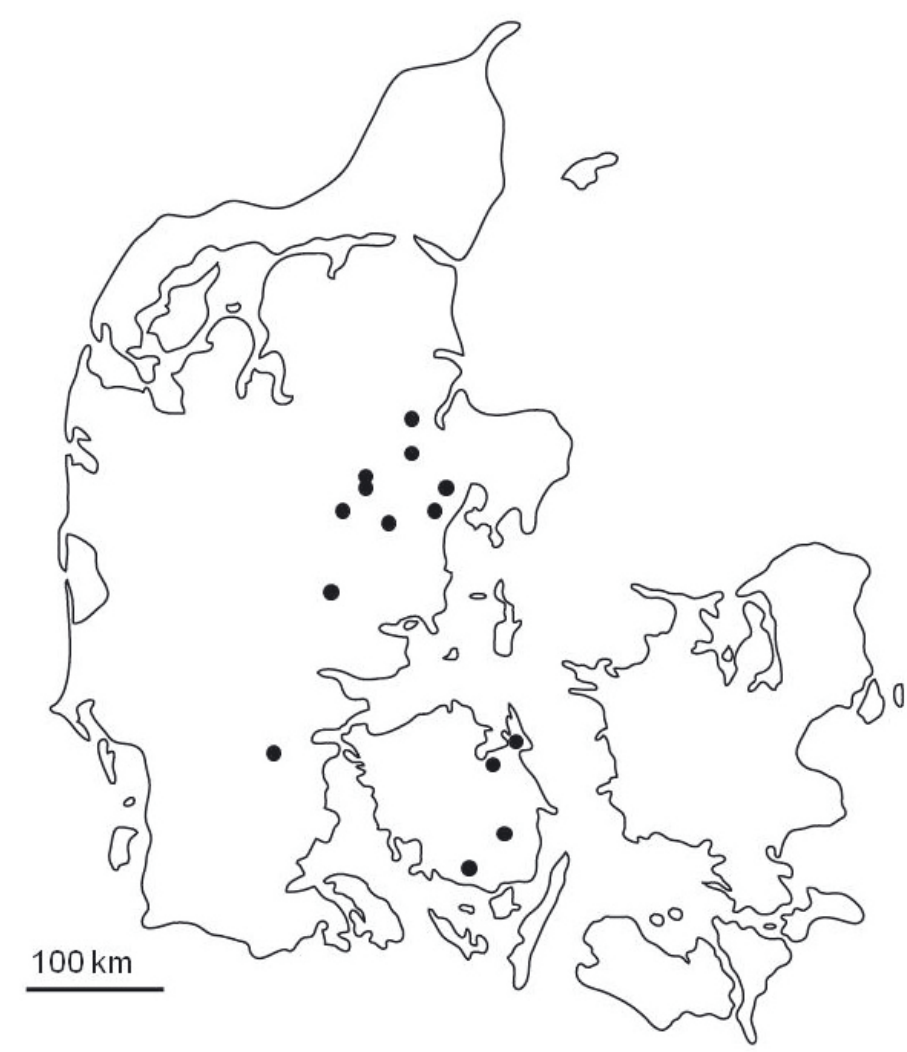

Figure 1. Location of study sites.

Hunsballe Frø A/S. The yield was in normal quality $\mathrm{kg}$ pr. ha, i.e. the total amount of yield adjusted for cleanness and ability to germinate.

\subsection{Data analysis}

Bumblebee activity was calculated as individuals/ha/hour. Bumblebee individuals were categorized into castes (queens, workers and males) and identified to the species level. Data were then grouped into: (1) all queens, (2) all workers, (3) workers of short-tongued species, (4) workers of long-tongued species, and (5) workers of Apis mellifera.

Activity levels of bumblebee groups and honeybees were tested against field characteristics (see below). Because of small sample sizes we used the non-parametric Kruskal-Wallis test for the withinfield analyses. For the remaining analyses, we used parametric tests (linear regression and ANOVA), using appropriate transformations to meet the assumptions of parametric tests. All analyses were done in JMP 7.0 (SAS Institute).

For each of the 14 study fields, we investigated the effect of the following factors within the field:

- Season (early, mid, late in the flowering period of the field).

- Time of the day (before noon or afternoon).

- Place of plot in the field (edge, intermediate, center).

Because the latter two factors were non-significant in most instances, we pooled data within fields for each sampling day. We then compared bumblebee group activities across different fields. Because bee activity levels changed seasonally, for each field we used the maximum observed bee activity level as a representative value of the field's capacity to support bumblebees. In the across-fields analysis, we compared activity data for the date of peak activity of bumblebees (mostly mid season) and honeybees 
(mostly end of season) in relation to the following variables:

- Field size (in ha).

- Presence/absence of commercial honeybee hives.

- Proportion of weeds (non-red clover).

Lastly, we tested correlations between yield ( $\mathrm{kg}$ red clover seed per ha), field characteristics and bee group maximum activity levels.

\section{RESULTS}

\subsection{Species richness of Bombus}

We generally observed few species of Bombus. A total of ten species were observed, of these four were observed in all study fields, three were observed in some fields, while three species were only registered once each (Tab. I). On average, we observed a total of $6.3 \pm 0.6$ Bombus spp. with a maximum of seven species per field during the entire season. On one observation day, we observed $5.0 \pm 1.1$ Bombus spp. per field. Species accumulation curves mostly reached saturation after 30-40 min of observation. Observation time per day per field was $103 \pm 48 \mathrm{~min}$.

Fairly high abundances of Bombus individuals were observed throughout the season. We found a general dominance of individuals of the Bombus terrestris complex. Furthermore, the majority of Bombus individuals observed were of the worker caste (Tab. II).

\subsection{Differences in abundances within fields}

No significant difference was found in abundances of all bumblebee groups at all 14 localities in plots at the edge, intermediate or center of the field (Kruskal-Wallis test: all $P>0.05$ ). Furthermore, for most Bombus groups and localities, no diurnal variation was found in abundances. Exceptions included two fields, in which total, short-tongued and longtongued bumblebee workers had significantly higher abundances before noon. Honeybee activity differed significantly between before and after noon in two fields, but in no consistent direction. In contrast, abundances of many bee groups at all localities were significantly or marginally significantly associated with time of the season. For all bumblebee groups, abundances mostly peaked in mid season, while honeybee abundances mostly peaked towards the end of the red clover flowering season. For this reason, we pooled data from different plots and data collected at different times of the day within localities. For each locality, we then selected the day with the highest total abundance of bumblebees (and for honeybees the day of maximum honeybee activity) for the amongfields analyses.

\subsection{Differences in abundances among fields}

Study fields varied in size ( 3 to 15.5 ha), weediness (2 to 60\%), presence/absence of honeybee hives, and seed yield ( 0 to $710 \mathrm{~kg} / \mathrm{ha}$ ) (Tab. III). One locality (Sall 2) was excluded from the analysis because of its outlier position (high proportion of weeds, late flowering, and no seed yield). For the remaining fields, maximum abundances of bumblebee groups and honeybees were not significantly associated with field size (linear regression, all $P>0.05$ ), although larger fields tended towards slightly lower maximum abundances of bumblebees.

Presence of commercial beehives did not affect total maximum abundances of queen and worker bumblebees, nor maximum abundances of short-tongued workers (ANOVA, all $P>0.05)$. However, the maximum abundance of long-tongued workers was significantly negatively affected by the presence of beehives (ANOVA: $\mathrm{df}=1, F=8.53, P=$ $0.01, R^{2}=0.44$, Fig. 2). Not surprising, honeybees had a significantly higher maximum abundance in the presence of hives (ANOVA: df $\left.=1, F=5.40, P=0.04, \mathrm{R}^{2}=0.33\right)$.

Common weeds in the red clover fields were flowering Cirsium arvense (L.) Scop., Carduus crispus L., Matricaria perforata Mérat, Trifolium repens L., Rumex L. sp., in addition to grasses. Flowering weeds were visited by both Bombus spp. and Apis mellifera. 
Table I. Species of Bombus observed in the 14 study fields (presence indicated by x).

\begin{tabular}{|c|c|c|c|c|c|c|c|c|c|c|}
\hline Location & 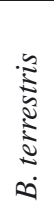 & 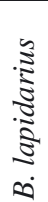 & 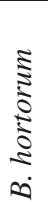 & 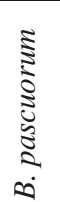 & 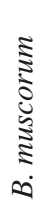 & $\begin{array}{c}0 \\
\vdots \\
\vdots \\
\vdots \\
\vdots \\
\vdots \\
\vdots \\
0\end{array}$ & $\begin{array}{l}\vdots \\
\vdots \\
\vdots \\
\vdots \\
\vdots \\
\vdots \\
\infty\end{array}$ & 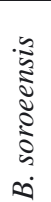 & 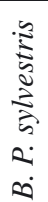 & 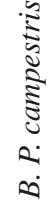 \\
\hline Lem & $\mathrm{x}$ & $\mathrm{x}$ & $\mathrm{x}$ & $\mathrm{x}$ & $\mathrm{x}$ & $\mathrm{x}$ & $\mathrm{x}$ & & & \\
\hline Brushøjgård & $\mathrm{x}$ & $\mathrm{x}$ & $\mathrm{x}$ & $\mathrm{x}$ & $\mathrm{x}$ & & $\mathrm{x}$ & & & \\
\hline Hesselballe & $\mathrm{x}$ & $\mathrm{x}$ & $\mathrm{x}$ & $\mathrm{x}$ & $\mathrm{x}$ & $\mathrm{x}$ & $\mathrm{x}$ & & & \\
\hline Skejby & $\mathrm{x}$ & $\mathrm{x}$ & $\mathrm{x}$ & $\mathrm{x}$ & $\mathrm{x}$ & & & & & $\mathrm{x}$ \\
\hline Gjern & $\mathrm{x}$ & $\mathrm{x}$ & $\mathrm{x}$ & $\mathrm{x}$ & $\mathrm{x}$ & $\mathrm{x}$ & & & & \\
\hline Galten & $\mathrm{x}$ & $\mathrm{x}$ & $\mathrm{x}$ & $\mathrm{x}$ & $\mathrm{x}$ & $\mathrm{x}$ & $\mathrm{x}$ & & & \\
\hline Sall1 & $\mathrm{x}$ & $\mathrm{x}$ & $\mathrm{x}$ & $\mathrm{x}$ & $\mathrm{x}$ & $\mathrm{x}$ & & $\mathrm{x}$ & & \\
\hline Sall2 & $\mathrm{x}$ & $\mathrm{x}$ & $\mathrm{x}$ & $\mathrm{x}$ & $\mathrm{x}$ & $\mathrm{x}$ & & & & \\
\hline Brædstrup & $\mathrm{x}$ & $\mathrm{x}$ & $\mathrm{x}$ & $\mathrm{x}$ & $\mathrm{x}$ & $\mathrm{x}$ & $\mathrm{x}$ & & & \\
\hline Vamdrup & $\mathrm{x}$ & $\mathrm{x}$ & $\mathrm{x}$ & $\mathrm{x}$ & & & $\mathrm{x}$ & & & \\
\hline Seden & $\mathrm{x}$ & $\mathrm{x}$ & $\mathrm{x}$ & $\mathrm{x}$ & $\mathrm{x}$ & $\mathrm{x}$ & & & & \\
\hline Mesinge & $\mathrm{x}$ & $\mathrm{x}$ & $\mathrm{x}$ & $\mathrm{x}$ & $\mathrm{x}$ & & & & $\mathrm{x}$ & \\
\hline Ryslinge & $\mathrm{x}$ & $\mathrm{x}$ & $\mathrm{x}$ & $\mathrm{x}$ & & $\mathrm{x}$ & $\mathrm{x}$ & & & \\
\hline Vester Skerninge & $\mathrm{x}$ & $\mathrm{x}$ & $\mathrm{x}$ & $\mathrm{x}$ & $\mathrm{x}$ & $\mathrm{x}$ & & & & \\
\hline
\end{tabular}

Table II. Numbers of individuals of Bombus species, groups and castes, in addition to Apis mellifera individuals observed during the study.

\begin{tabular}{lcccc}
\hline Bombus species & Tongue & & & \\
& length & & & \\
\hline B. terrestris & Short & 118 & 6916 & 33 \\
B. hortorum & Long & 32 & 486 & 3 \\
B. hypnorum & Long & - & 11 & 1 \\
B. lapidarius & Long & 37 & 2233 & 37 \\
B. pratorum & Short & 1 & 27 & - \\
B. pascourum & Long & 1 & 2317 & 2 \\
B. muscourum & Long & 3 & 282 & - \\
B. Psithyrus sylvestris & - & - & - & 1 \\
B. P. campestris & - & 1 & - & - \\
Total Bombus & & 193 & 12272 & 77 \\
Total short-tongued & & & 6943 & \\
Total long-tongued & & & 5329 & \\
& & & 5449 & \\
Apis mellifera & & & & \\
\hline
\end{tabular}

Proportion of weeds in the fields was not associated with maximum abundances of bee groups, except for the maximum activity of honeybees, which decreased with increasing weediness of the field (linear regression: Slope $=-45.08, F=6.07, P=0.03, \mathrm{R}^{2}=$ $0.36)$.
Seed yield (kg/ha) was not significantly associated with presence of honeybee hives (ANOVA: $P>0.05$, Fig. 3), field size or the maximum abundances of any bumblebee groups or honeybees in the fields (linear regression, all $P>0.05)$. However, yield was marginally lower in weedy fields (linear 
Table III. Characteristics of study fields.

\begin{tabular}{lccccc}
\hline Locality & $\begin{array}{c}\text { Method of } \\
\text { cultivation }\end{array}$ & $\begin{array}{c}\text { Field } \\
\text { size (ha) }\end{array}$ & $\begin{array}{c}\text { Honey bee } \\
\text { hives } \\
\text { (number) }\end{array}$ & $\begin{array}{c}\text { Weediness } \\
(\%)\end{array}$ & $\begin{array}{c}\text { Yield } \\
\text { (kg per } \\
\text { ha) }\end{array}$ \\
\hline Lem & Organic & 10.8 & $+(12)$ & 10 & 491 \\
Randers & Organic & 14.7 & - & 20 & 128 \\
Hesselballe & Organic & 7.5 & $+(14)$ & 5 & 710 \\
Skejby & Organic & 15.5 & $+(22)$ & 5 & 621 \\
Gjern & Organic & 8 & - & 30 & 51.72 \\
Galten & Organic & 3 & $+(20)$ & 5 & 129 \\
Sall 1 & Organic & 10 & $+(24)$ & 5 & 340 \\
Sall 2 & Organic & 12.53 & - & 60 & 0 \\
Brædstrup & Organic & 13 & $+(14)$ & 15 & 314 \\
Vamdrup & Organic & 8 & $+(12)$ & 5 & 137.88 \\
Seden & Organic & 10.3 & - & 30 & 187.71 \\
Mesinge & Conventional & 6 & - & 5 & 474 \\
Ryslinge & Conventional & 11 & $+(7)$ & 2 & 400 \\
Vester Skerninge & Organic & 9.5 & - & 10 & 208 \\
\hline
\end{tabular}

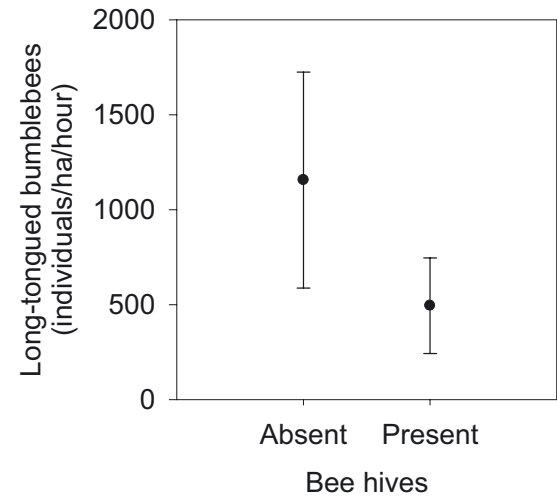

Figure 2. Maximum abundance of long-tongued bumblebees (individuals/ha/hour) in fields with and without commercial honeybee hives (Sall2 excluded).

regression: Slope $=-11.73, F=4.72, P=$ $\left.0.05, \mathrm{R}^{2}=0.30\right)$.

\section{DISCUSSION}

Although a total of 29 species of Bombus have been described from Denmark, many are rare, some possibly extinct (Madsen, 2009). In the current study, we only observed ten species, and of these only seven were repeatedly observed. Fields in different locations differed in abundances of bumblebee groups in

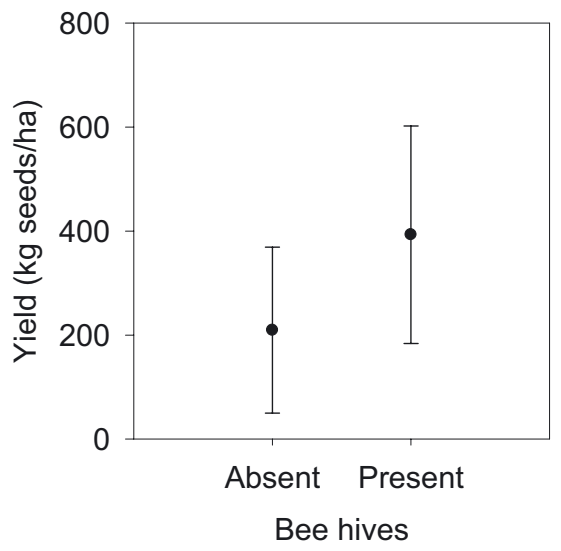

Figure 3. Seed yield of red clover in fields with and without commercial honeybee hives (Sall2 excluded).

addition to honeybees. However, within a field, abundances only appeared to vary through the season, and not with spatial location, nor time of the day.

\subsection{Seasonal differences}

Different bee species have different temperature thresholds, below which foraging does not normally occur, e.g. $5-12{ }^{\circ} \mathrm{C}$ for Bombus 
spp. and $11.3^{\circ} \mathrm{C}$ for Apis mellifera (Corbet et al., 1995). However, as all our bee observations were carried out above this threshold (minimum temperature was $14.8^{\circ} \mathrm{C}$ ), diurnal or seasonal temperature differences should not affect our results. The mid-seasonal peak of bumblebee activity is likely attributed to the availability of red clover flowers in the field, which peaked in mid season (data not shown). The phenology of the bumblebees, e.g. production of new queens in late season or interspecific differences in seasonal activity periods, was generally not mirrored in the abundances of bumblebee groups in the fields. Perhaps this is due to the relatively short flowering period of red clover, and to high between-colony variability in bumblebee phenology. Honeybees, however, were not abundant until late in the flowering season. Honeybees are generally thought to have difficulties exploiting the long-tubed flowers of red clover due to their short tongue length (Free, 1993; Delaplane and Mayer, 2000; Brødsgaard and Hansen, 2002). However, exceptionally dry and warm conditions may lead to a high nectar standing crop in red clover, thus providing optimal conditions for the honeybees to forage on red clover (Free, 1993). In fact, these conditions applied to the late red clover flowering season of 2008 .

\subsection{Effect of field characteristics and surroundings}

Species assemblages of bumblebees varied among the 14 localities of the study. At all locations, B. terrestris was the most abundant species, while the second most common species was $B$. lapidarius, B. pascourum or $B$. hortorum. The difference in bumblebee species assemblages recorded among fields is unlikely to be explained by regional differences in the bumblebee fauna, because assemblages of closely located fields sometimes differed. The fields included in this study, however, were highly heterogenous in size, shape, weediness, management and surroundings.

We found that field size did not affect recorded bumblebee and honeybee abundances. However, the influence of field size on seed yield in bee pollinated crops has been debated. While one study detected no effect of field size on seed yield in red clover (Brødsgaard and Hansen, 2002), another found decreasing yields for larger fields (Hawkins, 1958). A critical size of 12 ha for adequate pollination has been reported for field bean (Vicia faba) (Bond and Pope, 1974; J.B. Free and Williams, 1976). One hypothesis explaning the negative effect of field size is that bumblebees nest in the field margin (Skovgaard, 1936; Osborne et al., 2008b), and preferentially forage close to their nests (Goulson, 2003). However, in the current study, field sizes were generally small $(<15.5 \mathrm{ha})$, and even for door step feeders, the distance between the edge and center of the field may fall within their normal foraging range, i.e. a few hundred meters (Darvill et al., 2004; Knight et al., 2005). In conclusion, within the interval of red clover field sizes currently in use, the effect on bumblebee abundances were minor if any. Furthermore, yield was unaffected.

\subsection{Commercial honeybee hives}

The effect of commercial beehives on bumblebee abundances is difficult to assess. Honeybees regularly fly several $\mathrm{km}$ to collect nectar (Visscher and Seeley, 1982), and hence may visit the red clover field from nearby hives, even if hives are not placed by the farmer. Presence of honeybee hives did, however, result in a high activity level of honeybees in the red clover fields, and within a field honeybees were particularly abundant in the field closest to the hives (pers. obs.).

No significant difference was found in seed yield between fields with and without commercial honeybees. As mentioned above, honeybees are generally not thought to be good pollinators of red clover because of their short tongue length (Free, 1993; Delaplane and Mayer, 2000; Brødsgaard and Hansen, 2002). In the present study, weeding appeared a more important factor than the pollination service provided by honeybees in terms of elevating seed yield. 
The presence of beehives did not affect the total number of queens or worker bumblebees, nor short-tongued workers. However, it had a negative effect on long-tongued workers (Fig. 2). Forup and Memmott (2005) detected a negative correlation between abundances of Bombus spp. and honeybees in lowland heath areas. Although these results are not conclusive evidence of competition, it cannot be ruled out that honeybees act as superior competitors to long-tongued bumblebees for nectar. Because several long-tongued species are in decline (Goulson, 2005; Benton, 2006), we caution against an excessive use of commercial honeybees. Long-tongued bumblebees are thought to be superior pollinators of red clover (Free, 1993), and their decline may potentially reduce pollination, and hence seed set. However, low abundances of long-tongued bumblebees did not presently translate into reduced seed yield in red clover.

On the other hand, presence of honeybees may affect bumblebee abundances negatively by other means than competition. Because honeybees and bumblebees are closely related, and furthermore work in close proximity in the red clover fields, cross-species infection potentially occurs (Goulson et al., 2008). However, a preliminary test of individuals of three Bombus spp. collected in red clover fields showed no evidence of spill-over pathogens from Apis mellifera (P. Kryger, unpubl. data).

\subsection{Pesticides}

Other farming practices may affect bumblebee abundances and diversity negatively. In the current study, bumblebee and honeybee activity did not differ between organic and conventional fields (data not shown). However, of the 14 fields included in the study, only two were conventional (Tab. III), and sample sizes thus too small to answer this question. Very little is known about the effect of pesticides on bumblebees. In red clover fields, the insecticide Karate 2.5 WG is applied against seed predators, particularly the clover seed weevil Apion Herbst spp. and the lesser clover leaf weevil Hypera nigrirostris (F). Pesticides are risk assessed on honeybees, and instructions for use include spraying in late evening, when honeybees do not forage (directions for use and safety information, www.syngenta.dk). Bumblebees may be affected differently because of their longer diurnal activity periods, smaller colonies, which produce sexuals during a limited period, larger and more variable body size, and larger nectar carrying capacity per foraging trip (Thompson and Hunt, 1999; Thompson, 2001). Preliminary observations indicated that bumblebee abundances decreased up to 7-11 days after spraying in a red clover field (Y.L. Dupont and K.H. Wermuth, unpubl. data). This, however, is an area in urgent need of further investigation.

\subsection{Conclusions}

We conclude that bumblebee species composition and functional group abundances differed among red clover fields in Denmark. Bumblebee abundances mostly peaked in mid season, but no diurnal or spatial difference was found in bumblebee activity levels within each field. The peak activity of bumblebee groups was not associated with field size or weediness. Presence of honeybee hives affected the abundance of long-tongued bumblebee workers negatively, while seed yield was not significantly improved. Honeybee abundances mostly peaked in the late flowering season of red clover. The influence of pesticides on bumblebee activity and seed yield is unknown.

\section{ACKNOWLEDGEMENTS}

We thank Henning B. Madsen for identifying bumblebee specimens and Vibeke Simonsen for field assistance. Furthermore, we acknowledge the seed companies DLF Trifolium Denmark and Hunsballe Frø A/S for providing useful information, including contact details of the red clover farmers. We thank the farmers for allowing us to carry out field work in their red clover fields. Beate Strandberg, Dennis Boll and two anonymous referees are thanked for constructive comments on the manuscript. This study was financially supported by the Carlsberg Foundation and Aarhus University Research Foundation (to YLD). 
Effets des caractéristiques du champ sur l'abondance des bourdons (Bombus spp.) et sur la récolte de graines dans les champs de trèfle des prés.

Apis mellifera / pollinisation des cultures / bourdons à trompe courte / bourdons à trompe longue / Trifolium pratense

\begin{abstract}
Zusammenfassung - Die Effekte von Feldeigenschaften auf die Dichte von Hummeln (Bombus spp.) und den Ertrag in Rotkleefeldern. Rotklee (Trifolium pratense) ist eine wichtige Anbaupflanze in der biologischen Landwirtschaft. Die Blüten werden hauptsächlich von Hummeln (Bombus spp.) und Honigbienen (Apis mellifera) bestäubt. Umgekehrt ist Rotklee eine der wichtigsten Nahrungsquellen für Hummeln, insbesondere für Arten mit langen Rüsseln. Jedoch nimmt die Häufigkeit von Rotklee in Nordeuropa seit etwa 1950 ab.
\end{abstract}

In dieser Arbeit untersuchten wir den Effekt auf Artenreichtum und Individuendichte von Hummeln und von Honigbienen in 14 Feldern mit Rotklee in Dänemark (Abb. 1, Tab. I). Jedes Feld wurde während der Blütezeit dreimal besucht und dabei die Anzahl der Bienen in drei Quadraten von $18 \mathrm{~m} \times 18 \mathrm{~m}$ bestimmt. Die dabei beobachteten Bienen wurden bis zur Art bestimmt und anhand von Rüssellänge und Kaste in einer von vier funktionellen Bombus-Gruppen kategorisiert: (1) alle Königinnen, (2) alle Arbeiterinnen, (3) kurzrüsselige Arbeiterinnen und (4) langrüsselige Arbeiterinnen, neben (5) Arbeiterinnen der Honigbiene. Die Individuendichten innerhalb jedes Felds wurden in Bezug auf die Tageszeit (vormittags oder nachmittags), den Ort (am Rand, in der Mitte, oder dazwischen), und die Saison (Anfang, Mitte, Ende) verglichen. Verschiedene Felder wurden danach bezüglich des Maximums der beobachteten Bienendichten im Verhältnis zur Feldgröße, des Unkrautvorkommens, und der Anwesenheit bzw. des Fehlens von kommerziellen Honigbienenvölkern verglichen.

Wir beobachteten insgesamt 10 Arten von Bombus spp. während unserer Studie, mit durchschnittlich $6.3 \pm 0.6$ Arten pro Feld (Tab. I). Hummeldichten waren hauptsächlich in der Mitte der Blütezeit am höchsten, während die Dichte der Honigbienen gegen Ende am höchsten war. Die höchsten Aktivitäten von Bienen waren im allgemeinen nicht mit den Eigenschaften der Felder gekoppelt. Jedoch waren die Dichten der langrüsseligen Hummeln in Feldern, wo kommerzielle Völker von Honigbienen aufgestellt waren, signifikant geringer (Abb. 2). Der Ertrag wurde weder durch die maximale Bienenaktivität, noch durch die Feldgröße, noch durch die Anwesenheit von Bienenvölkern beeinflusst (Abb. 3). Der Saatansatz war in Feldern mit weniger Unkraut geringfügig höher. Daher empfehlen wir für einen verbesserten Saatansatz eher das Jäten von
Unkraut als das Aufstellen von Bienenvölkern, was die Dichte der effektiven, langrüsseligen Bestäuber negativ beeinflussen könnte.

Apis mellifera / Bestäubung von Kulturpflanzen / Kurz- und langrüsselige Hummeln / Trifolium pratense

\section{REFERENCES}

Benton T. (2006) Bumblebees: The natural history and identification of the species found in Britain, Collins, London.

Bond D.A., Pope M. (1974) Factors affecting the proportions cross-bred and self-bred seed obtained from field bean (Vicia faba L.) crops, J. Agr. Sci. $83,343-351$.

Brødsgaard C.J., Hansen H. (2002) Pollination of red clover in Denmark, Danish Institute of Agricultural Sciences, Ministry of Food, Agriculture and Fisheries, DIAS report No. 71.

Carvell C., Roy D.B., Smart S.M., Pywell R.F., Preston C.D., Goulson D. (2006) Declines in forage availability for bumblebees at a national scale, Biol. Conserv. 132, 481-489.

Carvell C., Westrich P., Meek W.R., Pywell R.F., Nowakowski M. (2005) Assessing the value of annual and perennial forage mixtures for bumblebees by direct observation and pollen analysis, Apidologie 37, 326-340.

Colla S.R., Packer L. (2008) Evidence for decline in eastern North American bumblebees (Hymenoptera : Apidae), with special focus on Bombus affinis Cresson, Biodiv. Conserv. 17, 1379-1391.

Corbet S.A. (1995) Insects, plants and succession: advantages of long-term set-aside, Agric. Ecosyst. Environ. 53, 201-217.

Corbet S.A., Saville N.M., Fussell M., Prys-Jones O.E., Unwin D.M. (1995) The Competition Box: A Graphical Aid to Forecasting Pollinator Performance, J. Appl. Ecol. 32, 707-719.

Darvill B., Knight M.E., Goulson D. (2004) Use of genetic markers to quantify bumblebee foraging range and nest density, Oikos 107, 471-478.

Delaplane K.S., Mayer D.F. (2000) Crop pollination by bees, CABI Publishing, Wallingford.

Fitzpatrick U., Murray T.E., Paxton R.J., Breen J., Cotton D., Santorum V., Brown M.J.F. (2007) Rarity and decline in bumblebees - A test of causes and correlates in the Irish fauna, Biol. Conserv. 136, 185-194.

Forup M.L., Memmott J. (2005) The relationship between the abundances of bumblebees and honeybees in a native habitat, Ecol. Entomol. 30, 47-57. 
Free J.B. (1993) Insect pollination of crops, Academic Press, London.

Free J.B., Williams I.H. (1976) Pollination as a factor limiting the yield of field beans (Vicia faba L.), J. Agric. Sci. 87, 395-399.

Fussell M., Corbet S.A. (1992) Flower usage by bumble-bees: A basis for forage plant management, J. Appl. Ecol. 29, 451-465.

Goulson D. (2003) Bumblebees: their behaviour and ecology, Oxford University Press, Oxford.

Goulson D. (2005) Causes of rarity in bumblebees, Biol. Conserv. 122, 1-8.

Goulson D., Lye G.C., Darvill B. (2008) Decline and conservation of bumble bees, Annu. Rev. Entomol. 53, 191-208.

Grixti J.C., Wong L.T., Cameron S.A., Favret C. (2009) Decline of bumble bees (Bombus) in the North American Midwest, Biol. Conserv. 142, 7584.

Hawkins R.P. (1958) A survey of late flowering and singlecut red clover seed crops, J. Natl. Inst. Agr. Bot. 8, 450-461.

Kleijn D., Raemakers I. (2008) A retrospective analysis of pollen host plant use by stable and declining bumble bee species, Ecology 89, 1811-1823.

Knight M.E., Martin A.P., Bishop S., Osborne J.L., Hale R.J., Sanderson R.A., Goulson D. (2005) An interspecific comparison of foraging range and nest density of four bumblebee (Bombus) species, Mol. Ecol. 14, 1811-1822.

Knight M.E., Osborne J.L., Sanderson R.A., Hale R.J., Martin A.P., Goulson D. (2009) Bumblebee nest density and the scale of available forage in arable landscapes, Insect Conserv. Divers. 2, 116-124

Kosior A., Celary W., Olejniczak P., Fijal J., Krol W., Solarz W., Plonka P. (2007) The decline of the bumble bees and cuckoo bees (Hymenoptera: Apidae: Bombini) of Western and Central Europe, Oryx 41, 79-88.

Madsen H.B. (2009) Humlebier, in: Wind P. (Ed.), Den danske rødliste, Fagdatacenter for Biodiversitet og Terrestrisk Natur (B-FDC), Danmarks Miljøundersøgelser, Aarhus Universitet, Aarhus, http://www.dmu.dk/Dyr_planter/redlistFrame/ Artsgrupper/ (accessed on 4 February 2010) (in Danish).

Murray T.E., Kuhlmann M., Potts S.G. (2009) Conservation ecology of bees: populations, species and communities, Apidologie 40, 211236.

Osborne J.L., Martin A.P., Carreck N.L., Swain J.L., Knight M.E., Goulson D., Hale R.J.,
Sanderson R.A. (2008a) Bumblebee flight distances in relation to the forage landscape, J. Anim. Ecol. 77, 406-415.

Osborne J.L., Martin A.P., Shortall C.R., Todd A.D., Goulson D., Knight M.E., Hale R.J., Sanderson R.A. (2008b) Quantifying and comparing bumblebee nest densities in gardens and countryside habitats, J. Appl. Ecol. 45, 784-792.

Rasmont P., Mersch P. (1988) Première estimation de la dérive faunique chez les bourdons de la Belgique (Hymenoptera, Apidae), Ann. Soc. R. Zool. Belgique 118, 141-147 (in French).

Skovgaard O.S. (1936) Rødkløverens bestøvning, humlebier og humleboer, Kgl. Danske Vidensk. Selsk. Skr. Naturvid. og Math. Afd. Raekke 9, 1140 (in Danish).

Stapel C. (1933) Undersøgelser over humlebier (Bombus Latr.), deres udbredelse, trækplanter og betydning for bestøvning af rødkløver (Trifolium pratense L.), Tidsskr. Planteavl 39, 193-294 (in Danish).

Thompson H.M. (2001) Assessing the exposure and toxicity of pesticides to bumblebees (Bombus sp.), Apidologie 32, 305-321.

Thompson H.M., Hunt L.V. (1999) Extrapolating from honeybees to bumblebees in pesticide risk assessment, Ecotoxicology 8, 147-166.

van der Smissen J. (2001) Die Wildbienen und Wespen Schleswig-Holsteins - Rote Liste, Landesamt für Natur und Umwelt des Landes SchleswigHolstein, Flintbek (in German).

Visscher P.K., Seeley T.D. (1982) Foraging strategy of honeybee colonies in a temperate deciduous forest, Ecology 63, 1790-1801.

Williams P.H. (1988) Habitat use by bumblebees (Bombus spp.), Ecol. Entomol. 13, 223-237.

Williams P.H. (2005) Does specialization explain rarity and decline British bumblebees? - A response to Goulson et al., Biol. Conserv. 122, 33-43.

Williams P.H., Araujo M.B., Rasmont P. (2007) Can vulnerability among British bumblebee (Bombus) species be explained by niche position and breadth? Biol. Conserv. 138, 493-505.

Williams P.H., Colla S.R., Xie Z. (2009) Bumblebee vulnerability: common correlates of winners and losers across three continents, Conserv. Biol. 23, 931-940.

Williams P.H., Osborne J.L. (2009) Bumblebee vulnerability and conservation world-wide, Apidologie 40, 367-387. 